\title{
Metáforas políticas del asco en Hot Sur de Laura Restrepo y Plegarias Nocturnas de Santiago GAMBOA*
}

\section{Orfa Kelita Vanegas **}

\section{Resumen}

Este artículo reflexiona sobre la proyección del asco y su relación con los límites del cuerpo como efecto que traduce el orden sociopolítico contemporáneo. Desde dos novelas colombianas y un fundamento teórico sobre emociones políticas, se indaga la tensión simbólica entre cuerpos repudiados y organización social. La irrupción del asco como sentimiento público en la narrativa rastrea los modos en que la dimensión ontológica de lo humano se circunscribe a jerarquías meramente políticas.

Palabras clave: Novela colombiana, cuerpo, proyección del asco, identidad, orden sociopolítico.

\section{Political metaphors of Repulsion in Hot SuR by Laura Restrepo and Plegarias Nocturnas by SANTIAGO GAMBOA}

\begin{abstract}
This article reflects about the projection of the repulsion and its relation to the limits of the body as effect that translates the contemporary socio-political order. From two Colombian novels and a theoretic foundation about political emotions, it's investigated the symbolic tension between repudiated bodies and social organization. The irruption of the disgust as a public feeling in the narrative traces the manners in which the ontological dimension of the human it circumscribe to hierarchies merely policies.
\end{abstract}

Keywords: Colombian narrative, body, projection of the repulsion, identity, socio-political orders.

Recibido: 22-01-2016

Aceptado: 18-03-2016

Este artículo se inscribe en el proyecto de investigación Memoria narrativa del miedo político y la representación de sus efectos psicosociales en la literatura colombiana, en el marco de los estudios de Doctorado en Letras de la Universidad Nacional de Cuyo, Argentina.

* Colombiana. Doctoranda en Letras de la Universidad Nacional de Cuyo, Argentina. Profesora Asociada de la Universidad del Tolima, Ibagué, Colombia. okvanegasv@ut.edu.co 


\section{Introducción}

Las novelas colombianas Hot Sur (2012) de Laura Restrepo (1950) y Plegarias Nocturnas (2012) de Santiago Gamboa (1965), se ubican en el contexto de la tradición literaria que indaga lo emocional como efecto político del orden social. La irrupción de las emociones públicas en el espacio literario desafía los límites del campo sociopolítico que las domestica y acomoda a su interés; anima la capacidad creativa del autor para proponer otros acentos de las tensiones culturales -de género, «raza», clase social- que han agobiado el devenir del ser humano; y problematiza la conciencia ética del lector frente al acto propio y su sistema de valores. En relación con estos aspectos, el presente estudio pretende elucidar, desde el tema del asco como emoción política, la analogía simbólica entre bordes corporales y fronteras del orden social en las dos novelas elegidas. El asco como sentimiento público se configura a modo de vértice donde coinciden los trazos simbólicos de los lindes corporales con las líneas normativas que definen los límites de la organización social contemporánea. Las fronteras del cuerpo: los orificios y las sustancias que eyectan, emergen como metáfora del desprecio y la repugnancia que los sistemas gubernativos hegemónicos proyectan sobre la comunidad de los «países en desarrollo» por considerarla «elemento contaminante» de los valores institucionales.

Los textos de Laura Restrepo y Santiago Gamboa interrogan los modos sobre cómo los estados emocionales impactan directamente en la estructuración de una nación y el sostenimiento de una cultura política. Significan en torno a la red de sucesos y relaciones entre los personajes, las maneras como las emociones públicas se redirigen y cultivan hacia la conservación de los valores de la sociedad y se vuelven mecanismo fundamental en la deliberación de las conductas individuales y colectivas. Nussbaum $^{1}$ (2014), sobre estos procesos cognitivo-emocionales públicos ${ }^{2}$,

Para conceptualizar sobre emociones políticas se recurre, especialmente, a los reconocidos estudios de Martha Nussbaum. Consideramos su enfoque teórico porque sistematiza y reflexiona en sus libros el tema de las emociones desde diferentes pensadores y campos de estudio: psicología cognitiva, antropología, psicoanálisis, creando un cuerpo teórico y crítico sólido de profundas explicaciones filosóficas.

2 Un aspecto importante a tener en cuenta sobre las emociones es que implican siempre un acto cognitivo o razonado. Contraria a la creencia de que lo emocional surge espontáneamente como especie de impulso incontrolado o energía natural privada de pensamiento, es la certeza de que hay un contenido cognitivo-evaluativo en todo sentimiento que revela la percepción de un suceso 
afirma que todos «los principios políticos, tanto los buenos como los malos, precisan para su materialización y su supervivencia de un apoyo emocional que les procure estabilidad a lo largo del tiempo» (Nussbaum, Emociones 15).

Así entonces, la formulación literaria de los sentimientos colectivos ilumina no sólo el panorama de normas y paradigmas sobre el que se afirma el comportamiento social, sino, y, lo que es más importante, posibilita la evaluación de las coordenadas políticas que recurren a la manipulación de las emociones para infundir imaginarios colectivos sobre quien es considerado como "persona» y quien se queda por fuera de ese estatus. En el movimiento de las emociones, las obras de Restrepo y Gamboa ingenian un espacio de contestaciones donde se levanta un faro de miradas capaz de proyectar otras formas de sensibilidad y comprensión de los hombres y mujeres como sujetos sociales. Aunque predeterminados como «persona» por un esquema de valores, las subjetividades presentes en las narrativas logran exceder tal esquema para constituir su yo propio, y, a su vez, confrontar el orden gubernativo que fija límites más allá de los cuales siempre queda alguien, en condición de excluido.

La manifestación de las emociones sin duda se hace palpable en los gestos y fronteras del cuerpo. En Hot Sur y Plegarias Nocturnas la fuerza vital de los personajes se coliga a lo corpóreo, es decir, la trama narrativa toma consistencia y profundidad en el sentimiento y conciencia de cuerpo que tienen los protagonistas. Éstos se hacen tangibles en la forma como el lenguaje estético mapea el cuerpo, ya sea para significar la subjetividad que lo constituye o para negarla en su identidad. En la novela de Gamboa (2012), por ejemplo, La Tongolele, personaje transexual que aparece en uno de los apartados de «Monólogos de Inter-neta», recobra su identidad cuando logra tener, a través de intervenciones quirúrgicas, un cuerpo como el de Pamela Anderson, a quien ve como referente de

\footnotetext{
o realidad concreta. Cuando reaccionamos frente a determinadas circunstancias, las emociones "responden al recuerdo y la memoria" (Nussbaum, Emociones 164), pues el estar inmersos desde la infancia en un grupo social que defiende y labra un conjunto de emociones públicas, prefija, en gran medida, la personalidad individual y la relación con los otros. Siendo así, los juicios implícitos en las expresiones emocionales se relacionan de manera directa con la formación humana que se hereda.
} 
«mujer bonita», que, según la protagonista, es la única que «importa en este mundo» (84). Veamos:

hablo del cuerpo y no del alma [...] primero fueron las siliconas, el bótox, las costuras y remiendos, y luego, cuando me repuse de todo, empecé el trabajo físico. Tres horas de gimnasio al día. El bronceado me lo hago con productos PA [...] Yo cuido cada cosa, cada detalle, porque el cuerpo es una pintura. Digamos, para las que sean cultas, como La ronda noche de Rembrandt. Cada matica, cada orla del vestido, cada sombra, todo es perfecto. Así debe ser una si el objetivo es ser la más hermosa del mundo, o por lo menos de mi propio mundo, no seamos tan presuntuosas. (84)

En este pasaje la fijación de la apariencia física para proyectar el espíritu del personaje, evoca el cuerpo en el flujo de la realidad contemporánea. La línea de visibilidad y subjetivación de lo corpóreo se enfila con nuevas figuraciones en las que el sujeto se define no en lo que es, sino en lo que está dejando de ser. La Tongolele franquea categorías corporales como masculino, femenino, natural, único, etc., para abrir camino a la materialización del yo a imagen y semejanza del deseo propio. En este personaje se logra leer un imaginario colectivo de lo corpóreo, en el que el ser humano no opone ya alma y cuerpo, sino que de manera sutil se opone a su propio cuerpo en un efecto de desdoblamiento (Le Breton, Sociología 91). Y, así, una vez desdoblado en cuerpo, toda modificación anatómica gira en metáfora del símismo.

Si el cuerpo es el «lugar geométrico de la reconquista propia» (Le Breton, Antropología 45), el énfasis que los escritores hacen en él se relaciona con la emergencia de las fuerzas discursivas, políticamente articuladas, que definen qué individuos se reconocen como humanos y quiénes se quedan por fuera de ese rango y porqué (Butler 45). La anatomía circunscrita a un simbolismo excluyente define el valor del individuo en cuanto persona. Las características físicas: color de piel, talla, rasgos faciales, sexo, etc., ciertamente, se han constituido como indicativo para determinar qué individuo es aceptado o susceptible de rechazo. En contestación entonces a esta realidad, Hot Sur y Plegarias Nocturnas codifican las fronteras corporales como lugar indeterminado y ambiguo que no sólo remueve los paradigmas sociales, sino que también reubica al individuo en calidad de persona con una historia propia y un 
sello social. Trazas conceptuales como identidad, dignidad, legalidad, etc. son debatidas desde una reelaboración transgresora del cuerpo. Las excrecencias y marcas corporales -la cirugía estética, el tatuaje, la cicatriz de tortura, la deformación, las secuelas de la enfermedad-, se constituyen en las novelas como símbolo y lenguaje de reconocimiento que el sujeto excluido apropia para habitar su espacio íntimo y la zona invivible de la vida social.

\section{Sustancias viles y proyección del asco}

La temática que en Hot sur y Plegarias nocturnas canaliza la tensión simbólica entre corporalidad repudiada y orden social hegemónico, es el éxodo del colombiano a países del «primer mundo» por causas económicas, sociales o políticas. María Paz, heroína de Hot Sur, se establece en Estados Unidos con la ilusión de reencontrar a su madre y dar por cumplido su «sueño americano»; mientras que Juana, personaje de Plegarias nocturnas, huye a Japón para resguardar su vida de la barbarie política del país. Con estas protagonistas se entra de lleno a escenarios donde la precariedad, la intimidación y la animalización del otro data las circunstancias degradantes de quienes son valorados desde un marco de asco político; de aquellos que no son reconocidos como persona en la esfera sociocultural de países modelo de desarrollo humano, calidad de vida y democracia vigorosa.

Es necesario precisar aquí el concepto de asco para comprender su relación con lo político y la formulación que de él hace la narrativa. A saber, el asco o repugnancia, es una emoción especialmente visceral, que implica siempre «reacciones corporales intensas a estímulos que a menudo tienen características corporales muy marcadas» (Nussbaum, Paisajes 234). Su contenido cognitivo ${ }^{3}$ retiene el sentido del contacto con

\footnotetext{
El sentido cognitivo de las emociones se explica como reacción asociada al pensamiento. La emoción siempre es acerca de algo, es decir, tiene objeto: la identidad de un temor, por ejemplo, depende de algo, si este algo se elimina, esa emoción de temor desaparece. Asimismo, todo objeto de la emoción implica la apreciación de quien lo percibe, su carácter, por ende, es intencional. La relación emocional con el objeto entraña siempre una forma íntima de percibir e interpretar, una particularidad que resulta importante en la identidad de la emoción, ya que reconocer la diferencia entre miedo y aflicción, amor y odio, por ejemplo, no es tanto por el carácter del objeto, que puede no cambiar, cuanto por la forma de verlo. De esa manera, si las emociones se conectan con la percepción propia de aquello que las causa, es evidente que esa percepción, personal y deliberada, está cargada de creencias sobre ese objeto, lo que lleva, a su vez, a atribuirle valor o importancia significativa (Nussbaum, Paisajes 49-54).
} 
un residuo contaminante: casi siempre de carácter corpóreo, en el que la repugnancia se ancla a la concepción que el sujeto tiene de tal residuo. Por lo tanto, toda emoción de asco está motivada «principalmente por factores vinculados a las ideas: la naturaleza o el origen del elemento y su historia social» (235). Para ilustrar un poco más la complejidad del simbolismo del asco, Nussbaum en su libro Paisajes del pensamiento..., precisa que la excrecencia producto del cuerpo propio no es vista como inmunda cuando aun permanece dentro del cuerpo, sin embargo, se vuelve repulsiva y ominosa una vez que lo abandona. En orden entonces a este aspecto, se puede deducir que el punto de toque entre la emoción de asco y el sentimiento político se sitúa justamente, en la idea de expulsión del residuo, que, una vez fuera, vira en sucio y ajeno, en un elemento extraño y contaminado. Esta derivación del objeto íntimo en sucio, en analogía simbólica, se reproduce en el plano social; esto es, que así como el cuerpo humano contiene elementos que una vez excretados se les reduce a cosa repugnante, el cuerpo sociopolítico de la nación, por causa de sus leyes y normativas, también expele y repudia a muchas de las personas que lo conforman. De hecho, aunque parte de esas personas logran el respaldo jurídico de sus derechos como ciudadanos, el cuerpo nacional sigue considerándolas como intrusas y negándolas en su humanidad. En resumidas cuentas, el humano «otro», aquel que está por fuera de una especie de traza cultural-genética del colectivo dominante, se alza como ícono del asco, como excreción que el cuerpo de la nación, políticamente definido, desecha.

Los sucesos en Hot Sur se desencadenan cuando María Paz es encarcelada por asesinato. En torno a este personaje se estructura un discurso que denuncia las condiciones discriminativas, violentas y de acoso político que viven los inmigrantes en Estados Unidos. En este contexto, el cuerpo es convertido en blanco de violencia por quien se arroga el derecho de normativizar el proceder del otro. María Paz, por ejemplo, imputada por el FBI de delincuente peligrosa-sin haber cometido crimen-, recibe una paliza brutal por parte de los agentes. Paliza que le provoca un aborto (Restrepo 253-56). El abuso de la agresión y el control desmedido en este pasaje ficcional se escuda tras un discurso eufemístico que justifica el ultraje a la heroína como acto necesario para garantizar la seguridad colectiva. Cuando, realmente, la reclusión de María Paz ha sido más bien estratagema para desviar la atención de los organismos 
periodísticos y judiciales ante la corrupción del Departamento de Justicia Norteamericano: recuérdese que un grupo de agentes de esta institución, traficantes de armas, son quienes asesinan a Greg: expolicía traficante, y esposo de María Paz. Es así, en consecuencia, como la protagonista termina en la cárcel con una hemorragia vaginal crónica. El cuerpo en este caso gira en alegoría de lo atroz, en metáfora del asco político y en acusación explícita de la invisibilización de lo humano:

Según todo indica, deshacerme en sangre es un hecho que se va cumpliendo.

Es como si me hubieran quitado un tapón y por ahí me fuera vaciando. Como si al no poder salir de estos muros, hubiera decidido salirme de mí misma [...] Empecé con este drama recién llegada a Manninpox [...] Mi piel ya no es mía, yo me quedé sin piel, yo soy una que anda en carne viva. (Restrepo $180,253)$

En esta escena llama la atención el borramiento 4 que la protagonista hace de sí misma al subsumir su existencia a un residuo sangrante, a una sustancia abyecta. Es un pasaje que apunta directamente a los orificios corporales: "puntos de referencia que cortan y constituyen el cuerpo» (Kristeva 74). Toda materia expelida a través de ellos se considera marginal, con un potencial simbólico de contaminación, siendo la sangre una de las excreciones que causa mayor repulsa: «en la sangre está la plaga [afirma María Paz] todo se tolera menos la sangre, que marca el límite del aguante [....] una sola gota es suficiente para el contagio, una sola» (Restrepo 190-1). La sangre, en efecto, y especialmente la vaginal, es sustancia desagradable que causa repugnancia por estar asociada con lo sucio; ella siempre motiva asco porque el imaginario cultural la relaciona con las cosas manchadas o impuras. En el pasaje citado se carga de mayor resonancia semántica por tratarse de un aborto, una particularidad en la que rastreamos el simbolismo aciago de la sangre que no llega a convertirse en persona, de aquello que se expulsa hacia el exterior del linde humano.

Tomamos el término "borramiento" del campo de la medicina, donde se explica comola desaparición gradual del cuello uterino durante el proceso de parto para dar paso al bebé. Lo tenemos en cuenta porque si el borramiento hace alusión a la desaparición de una entidad anatómica, sin dejar de ser parte del cuerpo, puede, en analogía simbólica, equipararse con la invisibilización del sujeto en el organismo social. 
Mary Douglas (2007), retomando a Levy-Bruhl, sostiene que en algunas culturas la sangre menstrual y el aborto se consideran como una especie de ser humano manqué; es decir, que si la sangre no hubiese fluido se habría convertido en persona. El sangrado vaginal, por ciclo menstrual o aborto, «posee el rango imposible de una persona muerta que nunca ha vivido» (Douglas 115). Siendo así, y atendiendo a esa creencia, es inevitable comparar el significado del sujeto manqué con la impresión de borramiento del yo que acosa a la heroína de Restrepo. Es como, si al «deshacer[s] e en sangre», ella quedara del lado de esas personas muertas que nunca han vivido, como si su desecho sanguinolento la convirtiera en un ser humano manqué, en una vida humana excluida de la categoría de persona, de aquel que, aunque vivo, está muerto.

De manera significativa el simbolismo de la hemorragia de María Paz se establece como punto de tangencia en el que el concepto de nopersona se cruza con el de asco político. Cuando la heroína se compara con la sangre del aborto alegoriza su condición de inmigrante, de ser vil expelido por el sistema sociopolítico norteamericano. La narración, de esa forma, configura sus personajes como no-personas, como cosas abyectas desencadenantes del asco: excretados del cuerpo social dominante. La jerarquización de las vidas humanas a la postre, degenera en imaginarios y conductas segregacionistas, pues aunque humanos todos, hay quienes son valorados como persona y quienes se quedan por fuera de esa categoría ${ }^{5}$. En tales condiciones, es indiscutible que la dimensión ontológica de lo humano se reduce a lo meramente político, pues no por el hecho de ser humano se tiene el estatus de persona.

Sobre ese complejo orden de lo social, Esposito (2014) aclara que «si la categoría de persona coincidiese con la de ser humano, no habría necesidad de ella» (22). En una sociedad donde prima la facultad de incluir por medio de la exclusión, siempre existirán hombres y mujeres que no sean consideradas del todo como personas, pues «la categoría de quienes gozan de determinado derecho es definida sólo por contraste con quienes, al no ingresar en ella, resultan excluidos» (22), sujetos manqué.

Roberto Esposito en su libro El dispositivo de persona, indaga el recorrido genealógico del concepto de persona. Teniendo en cuenta razones de orden jurídico y religioso, el filósofo explica porqué algunos seres humanos son considerados como personas: plenas en derechos civiles, mientras que a otros se les deja del lado de las no-personas. Una distribución desigual que determina la vida de los hombres y las mujeres bajo la red de sujeción y dominio de los estrados políticos más poderosos. 
La novela de Restrepo, leída desde ese razonamiento de lo humano, demuestra que aunque el cuerpo social norteamericano está conformado por seres humanos: nativos e inmigrantes, estos últimos son negados en su humanidad. Simbólica y materialmente, en esa sociedad, hay vidas humanas que son reducidas a cosa, a algo que provoca repulsa y, por tanto, no entran en la esfera política de persona, y mucho menos en el horizonte valorativo de sujetos con libertad de pensamiento y acción.

La manifestación discursiva y estética de Hot Sur sobre la proyección del asco, surge de la tensión entre «los de arriba»y «los de abajo», «los del norte» y «los de sur», «los limpios» y «los sucios». Una organización vertical de la sociedad que se reproduce en todos los escenarios sociales de la realidad ficcional: hogares, hospitales, cárceles, empresas, etc., donde lo nauseabundo y lo abyecto se asocia siempre con las personas de la periferia, con los de raza negra, los latinos y todo tipo de forastero que no reúna las características culturales y físicas «del civilizado norteamericano» (Restrepo 124). Estas manifestaciones de desprecio, desde el lente del psicoanálisis, se motivan debido a un aprendizaje adquirido a partir de la niñez: el reconocimiento de nuestro cuerpo como organismo productor de sustancias viles, que implica la confesión de sabernos corruptibles y viscosos, confrontándonos así, de manera ambigua, con el yo propio. Una situación ante la que se reacciona de modo evasivo proyectando la inmundicia propia, el asco de sí mismo, hacia fuera, «de tal manera que en realidad no sea uno mismo el que suscite asco, sino otro grupo humano que, en su villanía y perversión, es una fuente de contagio que hay que mantener a raya» (Nussbaum, Paisajes 239). La discriminación étnica y racial que se cuestiona en Hot Sur, parece derivarse pues de la respuesta evasiva del asco por sí mismo, que alimentada por normas y paradigmas culturales excluyentes llega a desembocar en la negación absoluta del otro al considerarlo elemento contaminante:

No había defensa posible, a la civilización occidental se le estaba viniendo encima todo el Sur, el explosivo y atrasado Sur, el desmadrado y temible Sur, con sus miles de odiadores de gringos que venían subiendo en horda [...] avanzaba por Panamá, atravesaba Nicaragua, se dejaba venir como tsunami por Guatemala y México y era incontenible cuando se colaba por los huecos de la vulnerable frontera americana. Los del 
Norte ya tenían encima a la marea negra del Sur, la tenían adentro. (Restrepo 124)

La escena resulta interesante por el efecto de invasión que insinúa, por la sugerencia de que algo problemático está irrumpiendo en el cuerpo social norteamericano. La reacción de repulsión del narrador hacia la comunidad latina lo lleva a asociarla con una especie de virus o cosa contaminante que penetra el organismo social infectándolo ${ }^{6}$. En esa proyección del asco político la novela actualiza la idea de corrupción en la que «el yo se envilecerá o se contaminará por la ingestión de una sustancia que se considera desagradable» (Nussbaum, Paisajes 236). De ahí que, Ian Rose, narrador de la escena anterior, suponga que esa «marea negra del Sur», de «pésimo acento y sonrisa taimada» (Restrepo 125), está al acecho, «escondiendo Blackhawks Garra II entre el bolsillo» (125), dispuesta a rasgar el equilibrio de su sistema democrático y a abusar de sus bienes. Unido a esto, si se tiene en cuenta que todo orden político está estrechamente relacionado con un orden corporal (Le Breton, Antropología 40-2), y que el asco está ligado a los límites corporales y a la perspectiva de la ingestión o contacto con un elemento vil (Nussbaum, El ocultamiento 114-15), resulta claro que las jerarquías sociales y sus fines políticos: el cuerpo sociopolítico de la nación, se figuran en Hot Sur como alegoría de la problemática relación que el ser humano tiene con el cuerpo y sus excrecencias. Como ya se señalaba líneas arriba, el hombre asimila desde pequeño la forma de expeler la repulsión de sí mismo volcándola hacia los otros, especialmente hacia aquellos que piensa están «por debajo» del estatus de persona; actitud que señala a ese otro como amenaza latente para el círculo social, como cosa que infecta el cuerpo nacional que se supone inmaculado.

Si nos detenemos en el efecto de invasión del último pasaje citado de Hot Sur, es indudable que evoca el comportamiento animal en la forma como muestra a la comunidad latina ingresando a territorio

\footnotetext{
La relación entre sentimiento y pensamiento, en el que interfiere el esquema de objetivos y deseos personales en la estimación del objeto que suscita la emoción, es inseparable del yo, por eso ante situaciones negativas se siente que lo emocional lo vulnera, pues tiene que ver con lo íntimo y con lo que se valora como importante para el bienestar personal. Es esa faceta sentimental la que evidencia tanto la necesidad que el ser humano tiene de ciertas cosas y personas externas como la incapacidad de controlar esos "objetos bienes" importantes para la ventura particular. Así entonces, las emociones cuestionan nuestra autosuficiencia y nos hacen reconocer las necesidades propias y la potencial vulnerabilidad frente al otro (Nussbaum, Paisajes 49-54).
} 
norteamericano: «se le estaba viniendo encima [...] venían subiendo en horda [...] se dejaba venir como tsunami [...] era incontenible cuando se colaba por los huecos [...] ya [la] tenían encima [...] la tenían adentro (Restrepo 124). «Los del Sur», así representados, traspasan la frontera como especie de alimaña microbiana dispuesta a inocular el corazón de la nación estadunidense. Ciertamente, el esquema de valores que niega con fastidio al otro excluyéndolo de la esfera personal, empareja lo humano con la naturaleza del animal. La imagen de contaminación sujeta a la emoción de asco, corporiza un rechazo al contagio, que responde en gran medida al deseo de ser «no animal». Investigaciones de corte psicológico cognitivo $^{7}$, han puesto de manifiesto que las ideas que motivan el asco se desprenden del interés por custodiar los límites entre el ser humano y los animales o por refrenar la animalidad propia. Por ejemplo, toda secreción corporal, considerada como sucia, se asocia con lo animal, con lo que se tiene de común con ello, de ahí la repulsa y el rechazo a su contacto por estimarse contaminante -a estas excreciones se añaden los despojos y las cosas infectas que recuerdan la mortalidad y la corrupción si se ingirieran- (Nussbaum, El ocultamiento 106-120). Entonces, al hilo de esos razonamientos, la novela de Restrepo metaforiza los miedos y prevenciones del estadunidense frente al latino. Asociar a «la comunidad del Sur» (Restrepo 124) con la naturaleza del animal es suponerla como un dispositivo de contagio. El asco político que agita a Ian Rose en realidad lo que muestra es la latencia del imaginario de conjuración, tanto de la animalidad como de la mortalidad, de la condición animal que tanto impresiona al ser humano.

Si la proyección del asco se manifiesta cuando el otro es representado como «animal abyecto», como cosa que se opone decisivamente a lo humano propio, en palabras de María Paz, es porque «para ellos [la institucionalidad dominante] es importante convencerte de que has dejado de ser humano»(Restrepo 56). Manipulado políticamente, el asco niega «la realidad misma del cuerpo de los miembros del grupo dominante, que proyectan así su propia vulnerabilidad corporal en los miembros del grupo subordinando, y luego usan esa proyección como excusa para ahondar en la subordinación» (Nussbaum, Emociones

Paul Rozin y April Fallon, desde la perspectiva de Nussbaum, son parte de los investigadores más reconocidos sobre el tema de las emociones, especialmente la del asco. 
317). De esa manera, la categoría biopolítica de no-persona en la que se circunscriben los protagonistas de Hot Sur, corre en coherente paralelismo con la de animal vil que el asco político proyecta en el sujeto inmigrante. En la realidad ficcional, en suma, la distribución que el orden gubernativo estadounidense realiza de las subjetividades representadas entre persona y no-persona, entre vidas reconocibles y legibles socialmente, y vidas opacas al orden jurídico de la comunidad, guarda estrecha relación con la oposición ontológica entre humano y animal, «que fue una matriz de muchos sueños civilizatorios del humanismo» (Giordi 30).

Resumiendo, en orden a lo discutido en este apartado, se reconoce que lo literario, paradójicamente, penetra en lo inhumano para devolvernos a lo humano. La ficción que ofrece una nueva inflexión del engranaje sociopolítico no sólo lo deconstruye, sino que también, y ante todo, esclarece otras formas de pensamiento y actitud más inclusivas de las divergencias culturales. Hot Sur en la escenificación de los avatares del inmigrante, advierte lo fantasmal ${ }^{8}$ del tipo de pensamiento que excluye al otro como medida para sostener un imaginario de nación decente. Asimismo, de manera paralela a los vejámenes de los personajes, en la novela de Restrepo se escenifican relaciones afectivas entre personajes de culturas heterogéneas en las que prima la empatía: María Paz y Cleve, Mandra X y las reclusas, Ian Rose y Empera; se reconoce positivamente en varios momentos la figura del inmigrante; y se cuestiona el carácter ético y legal de las instituciones norteamericanas al ser foco de conductas corruptas por parte de los propios miembros. Un conjunto de situaciones que abren otras rutas para indagar la tensión entre cultura y política. En síntesis, Hot Sur significa la proyección del asco como una mala guía para los fines organizativos de carácter público, ya que, como se ha argumentado desde los estudios de Nussbaum, la repugnancia es altamente maleable en términos sociales, y, casi siempre, utilizada para negar y atacar la humanidad de las personas y grupos más vulnerables.

Fantasmal en el sentido que todo orden social con suelo jurídico es contingente, lo que es legal en un tiempo y sociedad determinada -el apartheid, por ejemplo- muchas veces se desintegra con las actitudes morales y éticas de las nuevas generaciones o rezuma otros efectos en contextos sociales de otro tipo. 


\section{La piel como mapa de lo íntimo}

A continuación se discute la relación del cuerpo, específicamente de la piel, que lo recubre y contiene, con la proyección del asco. Dado que la literatura retoma las formas y sentidos de la superficie corpórea, ilumina otros modos en que lo humano se hace reconocible política y socialmente. La piel transformada en mapa de lo íntimo interviene en la recuperación de lo personal, de la dignidad y la memoria: tanto individual como colectiva, del sujeto y la sociedad.

Se argumentó líneas arriba que la distribución desigual del valor de lo humano y de la consideración de algunos como persona, mientras que otros quedan por fuera de esa jerarquía, patentiza un ordenamiento político de los cuerpos. Una biopolítica, que, como expresó Foucault, determina la vida humana, donde el poder de «hacer vivir» ${ }^{9}$ (Foucault, 1984) que se atribuye el sistema organizativo hegemónico, traza o mutila las perspectivas del sujeto. Lo humano, en esas condiciones, se instituye no en el espacio de lo ontológico, sino en el de lo político, donde el cuerpo como materia subsume la trascendencia del ser. No obstante, en esta cosificación del cuerpo a causa del instinto de politización de la vida humana el hombre, en la circunstancia de lo corpóreo como «cosa», de manera paradójica, ingenia nuevas inflexiones para cohabitarlo y recuperar su valor ontológico. Frente al poder biopolítico que (des)posee el cuerpo, se moviliza un giro subjetivo de lo corpóreo que impulsa otros usos personales del cuerpo para ser en tanto cuerpo, y con ello recuperar la identidad. La posesión voluntaria del cuerpo por su legítimo propietario se abre así como perspectiva de emancipación del sujeto, que proyecta a su vez nuevos lenguajes para la lectura de lo humano en la realidad actual (Esposito 73-78).

Así como los orificios corporales se establecen como pasaje entre el universo íntimo y la zona social, la piel también «representa un elemento sustancial de conexión y, desde ese lugar, se impone como instrumento cultural y simbólico; un estatus que la proyecta simultáneamente al espacio de la ritualidad y la sociabilidad» (Martínez Rossi 18). Es

Para Foucault (1984), el "hacer vivir" se centra en el "establecimiento de la tecnología de doble faz -anatómica y biológica, individualizante y especificante, vuelta hacia las realizaciones del cuerpo y atenta a los procesos de la vida- [que] caracteriza un poder cuya más alta función no es ya matar sino invadir la vida enteramente" (83). 
quizás el órgano humano más visible, y por ello erigida como lugar de exhibición de lo abyecto y lo vergonzoso: las marcas deshonrosas del esclavo, del criminal o de la mujer infiel, son sólo algunos casos. Por su potencial simbólico, es esperable que la piel sea intervenida y reificada como espacio de contestaciones por la imaginación estética y cultural. En Plegarias Nocturnas (2012) se configura a modo de «diario privado». Juana, personaje central de la novela, tiene imágenes tatuadas por todo el cuerpo, que registran, de forma alegórica, su vida: signada por la violencia política colombiana, la migración, la prostitución y el hastío. La piel se reconoce en esta narrativa como archivo de «sí mismo», donde los tatuajes y las marcas que la recubren retienen el pasado de la heroína y son metáfora sugerente de lo íntimo y de la asunción del yo. Veamos:

Estaba desnuda y se miraba al espejo [...] Nunca había visto un cuerpo así, con extraños y enormes tatuajes: ideogramas japoneses, soles, ojos budistas, yins y yangs, y en su vientre un verdadero cuadro, ¿qué era?, dios santo, pude reconocerlo: ¡La gran ola de Kanagawa, de Hokusai! [...] Más abajo, en el muslo derecho, tenía una versión de La balsa de Medusa, de Géricault, y en el izquierdo [...] La novena ola, del ruso Iván Aivazovsky [...] Tres naufragios más una cantidad increíble de signos religiosos o místicos. A eso se sumaban cicatrices y quemaduras circulares que parecían transmitir algún mensaje [...] La miré sin mover un músculo, sin respirar para que no notara mi presencia [...] Me pareció la mujer más hermosa del mundo, y sentí que la amaba. [...] Luego me retiré sin hacer ruido y me fui a dormir, excitado, culpable, triste. (274-75)

En principio, hay que notar que la descripción del cuerpo de Juana está referida por alguien que la observa en secreto. La intención lúdica narrativa de un personaje testigo instaurado en la trama, acerca al lector a la vida íntima de la protagonista. Los sucesos toman densidad al pasar por el lente y la voz de esa tercera presencia, que decide, desde sus juicios subjetivos, lo que se muestra o no del personaje. Un truco formal que emplean las dos novelas de estudio para entrar en la vida de los héroes. En Hot Sur se adivina un(a) periodista, cronista o investigador(a), que entrevista a los personajes, consulta documentos privados: diarios, cartas, fotos, archivos, que luego organiza, redacta y refiere de forma coherente. En Plegarias nocturnas es un cónsul, especie de alter ego del 
autor, que se asume vicario de la memoria de aquellos que conoció años atrás para referir lo sucedido. Ahora bien, aunque la constante de los dos libros es la vida de los personajes traducida en forma de narración por un tercero, esta voz testigo también cede la palabra a quienes son el eje de su relato, ya sea transcribiendo sus textos íntimos -redactados en primera persona- o dándoles voz independiente para que se cuenten a sí mismos: «Empezaré por lo peor, señor cónsul. Lo peor de lo peor, que fue mi infancia» (15). Un conjunto de artilugios estéticos que generan cierto efecto de credibilidad y confianza sobre lo acaecido, de los que se deriva la ilusión de verdad de la experiencia de vida de ese yo -ficcionalreferido narrativamente.

Concedido que hay un yo, una vida íntima, que se produce en el acto narrativo que articula las novelas, quien relata se apoya en todo tipo de elementos personales de «grafía biográfica» que ayuden a desentrañarlo, no sólo en aquellos archivos que se configuran como palabra, sino también en los que interviene la imagen plástica. Es por esa razón que el narrador que observa a Juana desnuda, en el último pasaje que se citó, se detiene en la descripción de los tatuajes, pues en ellos la historia particular y la memoria también se hacen presente. Hay un yo manifiesto en el tatuaje cuando la imagen grabada representa el "sí mismo» de la protagonista; que, de alguna manera, tiene el mismo efecto del yo gramatical de los textos biográficos utilizados por el narrador testigo en la realidad ficcional: diarios, entrevistas, blogs. Se trata de grabados que construyen a Juana como persona y terminan situando su intimidad en un afuera, expuesta a la mirada de otros. Ciertamente, los tatuajes de la heroína, en su variabilidad simbólica, en el cruce de líneas y colores, narra diferentes pasajes de vida; se constituyen en lenguaje figurativo de su yo, en «narración autopictográfica»-ella decide qué imágenes y símbolos surcan su piel- que expresa los matices del tiempo vivido, los secretos, los sueños y las pesadillas.

Un aspecto sugestivo de los tatuajes de Juana es la recurrencia de imágenes marinas. El narrador destaca, con gran admiración, las pinturas tatuadas donde el mar es la figura central. De hecho, si se observa -en un escenario extratextual- cada uno de los cuadros que la heroína lleva en su piel, es ineludible notar que todos son alegoría de la fuerza amenazante del mar y de la confrontación del hombre con ese elemento. El ruido del oleaje, el gesto desesperado del náufrago, la alusión a la muerte, el viento 
encumbrando la ola, entre otras, son escenas comunes en las pinturas, que fijadas en el cuerpo del personaje expresan el movimiento de una vida. El mar, para Juana, no es un mar quieto, ni abstracto, es el mar de Hokusai, de Géricault, de Aivazovsky, una fuerza precipitada, frenética, que exige resistencia al humano que lo encara. Es el mar, en analogía simbólica, que la habita y la desborda, un piélago alegórico de su conciencia, de su devenir, del jadeo con el que ha atravesado cada palmo de la existencia: sus andanzas como prostituta, la persecución del miedo a causa de la violencia sociopolítica, la humillación en su relación marital y durante su episodio como inmigrante ilegal, la devastación emocional por la muerte del hermano. Así entonces, la potencia de la imagen marina convoca la intimidad de la protagonista, se instala como pasaje por donde transita su historia. En su cuerpo la inscripción del oleaje embravecido transmuta en lenguaje propio, en una narración del yo que preserva y exterioriza la verdad de una vida.

Por concordancia con lo anterior, vale hacer un pequeño paréntesis en el tema principal de este texto para citar aquí el interesante trabajo Signos cardinales (2008) de la artista colombiana Libia Posada, en el que dibuja minuciosamente una serie de mapas sobre los pies y las piernas de un grupo representativo de personas desplazadas por la violencia sociopolítica de Colombia. Cada figura es testimonio de los caminos transitados por la persona para proteger la vida propia y la de la familia. Esos mapas, con sus convenciones particulares, más que íconos que representan la violencia, son presencia directa de ésta, pues los caminos mapeados en el cuerpo de las víctimas producen el espacio y la vivencia desde y en la misma persona expuesta al desplazamiento. De igual modo, las rutas pintadas en la piel de los desplazados se extienden como lugar alternativo para repensar los ordenamientos políticos y cuestionar el poder gubernamental colombiano que, en su precariedad e indolencia, no garantiza la vida y el bienestar de todos los ciudadanos. Como trazos narrativos, tales mapas inscriben nuevamente en la esfera social las vidas de los desplazados; imágenes, que, en el mismo sentido que el tatuaje en la novela de Gamboa, recalan en la vivencia de un momento traumático, registran parte de una vida y se erigen como memoria, tanto personal como colectiva, de la realidad abrumadora del país.

Aunque el tatuaje y las marcas corporales en la tradición de algunas culturas resguardan el valor ritual de lo comunitario y actúan 
como sello social, sobretodo en las comunidades indígenas ${ }^{10}$, no pocas veces emergen como lenguaje impugnador del discurso sociocultural establecido, especialmente en las poblaciones contemporáneas industrializadas. Como aclara Martínez Rossi (2011), quien retoma a su vez los argumentos que Susan Benson expone en su artículo Inscriptions of the Self: Reflections on Tattooing and Piercing in Contemporary EuroAmerica, las marcas y tatuajes corporales tienden a identificarse con «lo auténtico, lo incómodo, lo puro, en oposición con las corrupciones de la sociedad dominante» (Martínez Rossi 197). Inscribir sobre la piel ciertas marcas o imágenes es una forma de reivindicar la «autenticidad corporal ocluida por las disciplinas de la conformidad contemporánea» (197). El tatuaje así, se sostiene como ícono de lo anti-represivo, como emblema que frena o confronta el dominio del otro. Una actitud constante en las tribus urbanas actuales, sin embargo, donde más emerge es en el espacio carcelario; se sabe que la persona recluida encuentra en las intervenciones de la piel una forma de liberación e identificación, que implica igualmente el desafío al sistema que la excluye de la esfera social y que la ubica, casi siempre, al margen de lo humano.

Entre los escenarios ficcionales que Hot Sur construye está la cárcel de mujeres Manninpox, lugar por antonomasia de la proyección del asco y de negación de la particularidad humana. A través de ese espacio la novela denuncia abiertamente el sistema carcelario norteamericano por su tendencia a cercenar la humanidad de las personas. Las mujeres de Manninpox pierden su nombre una vez apresadas: son identificadas con un número serial, soslayando así su identidad de sujetos ${ }^{11}$; también, a las hispanas se les prohíbe hablar en su lengua materna: la comunicación debe hacerse en inglés, incluso durante la visita de los familiares; y, asimismo, las reclusas latinas o negras son obligadas a realizar los oficios que se asocian con lo sucio, como limpiar letrinas o lavar las inmundicias de las celdas, mientras que las blancas gozan del privilegio del trabajo manual o de otras actividades menos humillantes (Restrepo 85-91).

10 Martínez Rossi (2011) precisa en su libro que entre los Cubeo-Tucano a la criatura recién nacida y trasladada de la choza del parto a la maloca comunal, se le pintaba la cara con manchas rojas con Bixa Orellana a manera de "jaguar", protector mítico de la casa comunal, adquiriendo así el "status humano" y la entrada al grupo social (200).

11 Explica Nussbaum (2014), que cuando las personas son designadas con un número en vez de llamarlas por su nombre, quienes tienen el poder sobre ellas se comportan peor porque se las representan como unidades deshumanizadas, no individuales (239). 
En consecuencia, entonces a esas condiciones de la vida carcelaria, las internas ingenian formas y lenguajes para resguardar, recuperar o traducir su intimidad humana; entre esas formas representacionales, por supuesto, la manipulación intencional del cuerpo y la piel es la más notable. El cuerpo marcado, tatuado y perforado aparece en la ficción como especie de «tótem de la provocación» (Martínez Rossi 24) o altar de la diferenciación y el autoengendramiento. De esa manera lo edifica Mandra X, reclusa líder de Manninpox, vocera y defensora de los derechos humanos:

Se había metamorfoseado a sí misma mediante todas las modalidades de lo que llaman intervención voluntaria sobre el propio cuerpo, y los tatuajes la rayaban de arriba abajo sin perdonar un palmo de piel, como si un niño armado de crayola azul se hubiera ensañado contra ella. Tenía los lóbulos de las orejas alargados y desprendidos de la cara. Las pestañas ausentes y las cejas borradas que le daban el aspecto inhumano de un Mazinger Z. Y luego estaba el pelo cortado al cepillo y cruzado por líneas de máquinas de afeitar, como un Nazca en miniatura. Más las narices agujereadas; el labio superior bífido y la lengua bifurcada; las mejillas, el cuello y las manos marcadas con escarificaciones (...) se había hecho inyectar los pezones con tinta y tatuar una corona de rayos alrededor de cada uno, como dos soles negros en medio del pecho. (Restrepo 308)

Desde la perspectiva psicoanalítica, la transformación corporal de Mandra X es símbolo de renacimiento de lo íntimo y savia identitaria que vitaliza su humanidad. Su cuerpo transfigurado es efecto del proceso propio de autoafirmación e individualización que toda persona privada de libertad necesita concretar. Las imágenes que la envuelven de arriba abajo, así como la modificación de algunos órganos, depara la «gradual anulación del ser anterior y [la] asunción de una identidad original en cuyo trasfondo subyacen fantasías de resurrección o autoengendramiento» (Reisfeld 121). Es decir, las escisiones, desprendimientos, escarificaciones y demás roturas, deshacen la forma natural del cuerpo de Mandra X para dar paso a una nueva realidad, a la expresión de un ser diferente no abarcable en el cuerpo original. Un fenómeno de renovación vital anclado a la idea de cuerpo como principio de individuación, que «funciona 
social y políticamente como sede del yo y como ontología del individuo: la sede de lo propio, de lo propio del yo y de la propiedad como principio humanizador, como norma de lo humano» (Giorgi 115). Por eso la protagonista una vez recluida, con un pasado cancelado y expuesta a la anulación de su humanidad por parte del sistema carcelario, aniquila su forma corporal original: inteligible, normada, y atada a un tiempo ido, para engendrar un nuevo cuerpo, y con ello la exteriorización de otra vida, la producción de una persona-sujeto que es en tanto posee un cuerpo cómplice de sus nuevos deseos y expectativas.

De hecho, la aniquilación de la forma natural del cuerpo de Mandra X, en perspectiva metafórica, inicia cuando comete filicidio. Recuérdese que ella está condenada a tres cadenas perpetuas por dar muerte a sus hijos trillizos, que «padecían una conjunción apabullante de malformaciones de nacimiento, como ceguera, sordera y retraso mental. La mujer se consagró a ellos hasta que cumplieron los trece años de edad, y en ese momento tomó la decisión de eliminarlos con sobredosis de narcóticos» (Restrepo 295). Esta decisión se funda cuando la protagonista es diagnosticada con un cáncer de vejiga, que le hace temer la indefensión en que quedarían sus niños al ella morir, «ante todo no quería morir dejándolos solos» (296). Así pues, con la latencia del cáncer en su cuerpo y la muerte de los hijos, esta Medea también sucumbe. Magdalena Krueger, nombre original de Mandra X, «muere en sus hijos», la enfermedad y el asesinato inhuman lo que fue; por esa razón su renacida forma corpórea alegoriza la muerte del cuerpo anterior, del nombre anterior, que es por tanto la suspensión de una individualidad, de una vida y lo que hubo en ella. Situación paradójica, en el sentido que, si bien el engendramiento de un cuerpo nuevo aniquila una vida pasada, también deviene vida, que en el caso de la protagonista, se concreta en la acción social y política, en su militancia defensora de los derechos humanos de las reclusas de Manninpox.

Restrepo produce una obra que se abre en diversas trayectorias de representación de lo humano en la sociedad contemporánea para debatir la vigencia política del orden social. Hot Sur, claramente, desdibuja las «formas correctas» del cuerpo de la nación cuando obliga a mirarlas desde el matiz corporal de sus personajes. El cuerpo monstruoso y desviado de Mandra X evoca la malformación de los hijos asesinados, que son, a su vez, presencia simbólica de todos aquellos «humanos 
otros»: persona potencial, semi-persona, anti-persona, no-persona ${ }^{12}$, entregados al silencio y la sumisión de las personas integrales que el organismo sociopolítico sano elige, de manera injusta, como referencia de vida humana digna. En definitiva, Hot Sur al igual que Plegarias Nocturnas, muestran que allí donde la violencia biopolítica o de orden social despersonaliza y deshumaniza, «la resistencia tiene que pasar por la restitución de la persona, la identidad, el nombre, la biografía» (Giorgi 211). El cuerpo tatuado o modificado intencionalmente, dentro de ese marco social represivo, es contestación al poder aplastante que ha adoptado como punto de partida la agresión y la vulnerabilidad del otro; es presencia simbólica que apuesta a la reposición del sujeto y su perspectiva vital.

\section{A modo de conclusión}

En relación con los aspectos argumentados a lo largo de este estudio, concluimos que tanto Plegarias nocturnas como Hot Sur hacen especial énfasis en el cuerpo humano, específicamente en sus fronteras, para figurarlo como umbral calidoscópico donde se cruzan diferentes perspectivas del ordenamiento político y social de la vida humana. La formulación literaria del cuerpo se compone, recompone y descompone en un sinnúmero de imágenes alegóricas de lenguajes o discursos contestatarios, que llevan al lector a salirse de su horizonte habitual para atravesar nuevas coordenadas conceptuales sobre la categorización de los cuerpos y su consecuente sentido de lo humano o inhumano.

La literatura, afirma Ovejero (2012), contiene una savia ética que pone en tela de juicio todo tipo de verdades en las que la persona cree «ciegamente» (115). La proyección sociopolítica de la narrativa y su diálogo con otros discursos, hila nudos imaginativos y epistémicos que desmitifican explicaciones de la realidad trincadas a ideas naturalizadas o al rechazo de criterios más esclarecedores. Se sabe que el poder simbólico de lo literario interroga las diferentes figuras de verdad

12 Roberto Esposito (2014) en su disertación sobre la jerarquización de los hombres, especifica que dentro de la categoría de persona hay una serie de grados diferentes, caracterizados por una cuantía de personalidad, que iría "del adulto saludable, el único al que le pertenece el título de verdadera y propia persona, al infante, considerado una persona potencial; al viejo, definitivamente inválido, entonces reducido a semi-persona; al enfermo terminal, al que se le atribuye el estatus de nopersona, y al loco, a quien corresponde el rol de anti-persona" (77). 
que estructuran la vida social; sobre todo la obra que se ubica en la encrucijada de las problemáticas que oprimen la sensibilidad del ser humano: caso concreto, la presencia del inmigrante y su fuerte sustrato de segregación al señalársele como persona de tercera categoría, tal como lo constituyen los libros elegidos para este estudio. Con certeza, la ficción que resguarda un contenido que linda con lo ético «ataca el núcleo de nuestros hábitos intelectuales, la rutina de nuestros corazones y cerebros. Nos persigue hasta nuestras estancias más privadas y descubre aquello que se encuentra oculto bajo las sábanas y que preferimos no ver» (65). De esa forma, las novelas de Laura Restrepo y Santiago Gamboa expulsan una fuerza que destruye las certidumbres, clausuran todo espacio para la evasión y obligan al lector a confrontar la abrumadora realidad. Toda ficción que desborda en preguntas sobre las estructuras que determinan el devenir de los hombres y las mujeres, conserva una ética implacable que remueve lo íntimo, que nos retira el velo que suaviza la mirada ante el panorama social atroz, donde el valor de lo humano depende de criterios arbitrarios y violentos.

La incursión de las emociones políticas en el ámbito literario, particularmente la del asco, da origen a una voz acusadora de la distribución injusta que el orden social y la administración biopolítica, hace de la vida humana al categorizar a hombres y mujeres entre persona y no-persona. La capacidad ética del artilugio narrativo apunta especialmente a reconstruir la realidad perdida; a recuperar la vida humana que ha quedado por fuera del límite de lo inteligible del marco legal, para devolverle su legitimidad simbólica y reubicarla como ángulo alternativo desde el que se vislumbran otras formas, más inclusivas, de lo humano. Las novelas de los escritores colombianos, en síntesis, exigen al ordenamiento sociopolítico contemporáneo que ser humano no esté sujeto a un derecho a ser humano, pues este criterio implica siempre la fijación -innegablemente abyecta- de alguien más allá de lo personal y, en efecto, del linde del cuerpo social dominante. 


\section{Referencias bibliográficas}

Butler, Judith. Marcos de guerra. Las vidas lloradas. Madrid, Paidós, 2010.

Douglas, Mary. Pureza y Peligro: un análisis de los conceptos polución y Tabú. Buenos Aires, Nueva Visión, 2007.

Esposito, Roberto. El dispositivo de persona. Buenos Aires, Amorrortu, 2014.

Foucault, Michel. Historia de la sexualidad I. La voluntad de saber. México, Siglo XXI, 1984.

Gamboa, Santiago. Plegarias nocturnas. Cundinamarca, Random House Mondadori, 2012.

Giorgi, Gabriel. Formas comunes. Animalidad, cultura, biopolitica. Buenos Aires, Eterna Cadencia, 2014.

Kristeva, Julia. Poderes de la perversión. Ensayo sobre Louis-Ferdinand Céline. México, Siglo XXI, 1990.

Le Breton, David. La sociología del cuerpo. Buenos Aires, Nueva Visión, 1992.

. Antropología del cuerpo y modernidad. Buenos Aires, Nueva Visión, 2002.

Martínez Rossi, Sandra. La piel como superficie simbólica. Procesos de transculturación en el arte contemporáneo. Madrid, Fondo de Cultura Económica, 2011.

Nussbaum, Martha. El ocultamiento de lo humano: repugnancia, vergüenza y ley. Buenos Aires, Katz, 2006.

_.. Paisajes del pensamiento. La inteligencia de las emociones. Madrid, Paidós, 2008.

__. Emociones políticas. ¿Por qué el amor es importante para la justicia? Barcelona, Paidós, 2014.

Ovejero, José. La ética de la crueldad. Barcelona, Anagrama, 2012.

Posada Libia. Signos Cardinales. Centro de memoria histórica. Web. En línea en http://centrodememoriahistorica.gov.co/museo/ oropendola/signoscardinales/index.php 
Reisfeld, Silvia. Tatuajes. Una mirada psicoanalítica. Buenos Aires, Paidós, 2004.

Restrepo, Laura. Hot Sur. Buenos Aires, Planeta, 2013. 
